\title{
From centre-stage to the wings: the process of cultural adjustment in Arrow of God and Tess of the D'Urbervilles
}

\author{
S. I. Akhuemokhan • R. A. Masagbor
}

Published online: 11 January 2011

(C) The Author(s) 2011. This article is published with open access at Springerlink.com

\begin{abstract}
The essay examines culture and cultural adjustment in two novels-Arrow of God by Chinua Achebe and Tess of the D'Urbervilles by Thomas Hardy. Using Edward Said's theory on culture as a foundation, it compares the relative elasticity of a fictional, precolonial West African society, Umuaro, with the relative stiffness of a fictional Victorian society, Wessex. The essay pictures culture as a large cell with core elements located at the centre, like a nucleus. The study then proceeds to apply this mental picture to the texts, seeing the two protagonists as analogous of core elements in their cultures and hence as equivalent to the nuclei at the centre of their respective cells. Both protagonists are pivotal figures initially. This is expressed symbolically in terms of the centralized position of the core elements in the cultural cell. At the end of the day, however, both protagonists have become social outcasts, which again is expressed symbolically in terms of the movement of the core elements away from the centre to the periphery. The essay concludes that the symbolic reproduction of culture re-inforces the literal one, and that Achebe and Hardy equally recognize the strengths and weaknesses of the communities they are describing.
\end{abstract}

Keywords Culture $\cdot$ Cell $\cdot$ Element $\cdot$ Centralization $\cdot$ Marginalization

\section{Introduction}

In 1871, the anthropologist, Edward B. Tylor, ${ }^{1}$ defined culture lucidly and "in its widest ethnographic sense as that complex whole which includes knowledge, belief, art, morals, law, custom and any other capabilities and habits acquired by man as a member of society" (1). Elaborations, modifications, and streamlining of his classic definition have been made over the decades by intellectuals both inside and outside the discipline of anthropology. For instance,

1 Tylor (1871).

S. I. Akhuemokhan $(\bowtie) \cdot$ R. A. Masagbor

Department of English and Literature, University of Benin,

P.M.B. 1154, Benin City, Edo State, Nigeria

e-mail: sophyben@yahoo.com 
Roland Posner, ${ }^{2}$ a writer of both literary and sociological essays, identifies three types of culture: social culture (institutions and rituals transmitted from one generation to another); material culture (artifacts and skills transmitted in like manner); and mental culture (mentifacts and conventions also transmitted from one generation to another) (p. 254). A more recent contribution to the dialogue on culture comes from the versed Palestinian literary scholar, Edward Said. ${ }^{3}$ Said underscores the intricate relationship between culture and the text; in particular the literary text, an area where his studies are largely recognized as ground-breaking. He distinguishes two salient elements of culture which affirm the traditional viewpoints and at the same time are indicative of his innovations in the field of cultural criticism:

In the first place $[\ldots]$ culture is used to designate not merely something to which one belongs, but something that one possesses and, along with that proprietary process, culture also designates a boundary by which the concepts of what is extrinsic or intrinsic to the culture come into forceful play [....] But, in the second place, there is a more interesting dimension to this idea of culture... by virtue of its elevated or superior position to authorize, to dominate, to legitimate, demote, interdict, and validate: in short, the power of culture to be an agent of, and perhaps the main agency for, powerful differentiation within its domain and beyond it too. (pp. 8-9)

It is evident that Edward Said, like his predecessor and namesake Edward Tylor, views culture as a complete entity with discernible boundaries and a specific domain. There are concepts "intrinsic" to the culture, which fall within the boundaries, and there are concepts "extrinsic" to it. In addition, Said evidently construes culture as a differentiating force with a mandate to promote any given number of concepts - the beliefs, art, morals, laws, and so on outlined earlier by Tylor-or alternatively to downgrade them. Thus it is that culture can "authorize," "legitimate," and "validate," according to Said, or "dominate," "demote," and "interdict."

Said's definition is appealing and provides a befitting theoretical framework for this paper because it articulates so clearly the most fundamental principles of culture. His definition embodies a foundational element of Tylor's definition, which is the idea of culture as a complex whole comprising of multiple parts, and it goes beyond this to imply a continual sifting and sorting of the parts within the whole. Bearing this in mind, one can posit that the boundaries of culture shift with time and space, and that capabilities and habits that are central to a culture in one era can become periphery in another or even go into extinction. The nature of culture is such that this process of cultural phenomena shifting from core position to boundary-and thence perhaps into extinction-is ceaseless. We look at this process of shifting cultural phenomena in terms of cultural adjustment. Seen from this perspective, cultural adjustment is the relocation of the parts within the complex whole, whereby the "old" habits and capabilities recede to the borderlines of communal activity and new ones move to a core position. It presupposes the demotion of the former elements and the legitimization of the latter, to use Said's terminology. Therefore, adjustment may incorporate the notion of centralization, as certain phenomena are brought to the limelight; the notion of marginalization, as certain phenomena are relegated; and even the notion of demise, should the relegated phenomena ultimately die out entirely.

It is interesting to see how this theme is treated in two familiar novels: Arrow of God (AG) by Chinua Achebe ${ }^{4}$ and Tess of the D'Urbervilles (Tess or TD) by

\footnotetext{
2 Posner (1989).

${ }^{3}$ Said (1983).

${ }^{4}$ Achebe (1974).
} 
Thomas Hardy. ${ }^{5}$ Both novels depict cultures in the process of adjustment, and the continual positioning and re-positioning of the protagonists-Ezeulu and Tess respectively-figuratively reproduces the demotion of core cultural elements when the cultural whole is undergoing transition. It is a drama which takes the leading performers from centre-stage to the wings, and the manner and speed of their transference is a comment upon the two societies which can best be understood when the texts are placed side by side.

Cultural adjustment is a key topic in reviews on Achebe. As the literary analyst, Chidi Okonkwo ${ }^{6}$ avers: "A whole generation of Achebe critics has concentrated on the culturalconflict aspect of Achebe's plots and themes in his novel" (p. 105). He cites Emmanuel Ngara and Ossie Enekwe as object lessons. They exemplify a considerable body of critics who agree that Achebe's cultural-nationalistic novels hover around "cultural disintegration [...] ignor[ing] the fact that the same cultures which are supposed to have 'disintegrated' are also portrayed as triumphant" (pp. 105-106). Okonkwo is not persuaded that the disintegration of Igbo culture is Achebe's preoccupation, and he questions the tendency of reviewers to parallel the decease of the protagonists with the end of their ways of life. Towards the close of his paper he remarks:

The New Yam Feast crisis ends in a mass conversion of Umuaro to Christianity. Achebe suggests that this is a result of Ulu and Ezeulu's having mutually ruined themselves [... However] though Ulu and his priest are ruined, Umuaro is not. Critics who interpret the denouement to mean disintegration of Umuaro miss the fact that despite the stampede which characterizes the people's embracing of Christianity, the clan actually emerges whole from the ordeal, though significantly changed. In other words, Umuaro has triumphantly gone through its rites of passage and been reborn. (p. 119, emphasis added)

Okonkwo's observation that the clan "emerges whole" after having gone through its rites of passage is noteworthy. Culture as qualified by both Tylor and Said-that is in terms of a complex body comprising a variety of elements-would certainly bear this out. Indeed what Okonkwo perceives as change through rites of passage is approximate to the shifting, or reranking, of the parts within the whole. Nevertheless, Okonkwo does not press the matter. He proceeds with scholarliness to highlight Achebe's use of time and number as social documents, and to evaluate Ezeulu's task as "the reckoner of time and season in his community" (p. 108). We examine the mechanism of change slightly more thoroughly than Okonkwo because we believe it illuminates determinate aspects of the cultures depicted. Furthermore, we detect a tenuous bridge between the erstwhile parallel convictions on Achebe's portrayal of cultural adjustment; i.e. the conviction that the clan disintegrates as against the conviction that it triumphs. Assuming culture is a communal cell, it is feasible for the disintegration to take place at its borderlines even while the clan remains whole.

Culture is equally integral to discourse on Hardy's Tess. Numerous expositions have dwelt on the shortcomings of the Victorian lifestyle as portrayed in the text, especially in respect of its moral and social stringency. A popular example is Barron's Booknotes, ${ }^{7}$ which claim:

The Victorian Age in which Hardy lived was alive with contradictions and conflicts. While people were supposed to live in accordance with the Bible and ethics, they all

\footnotetext{
5 Hardy (1994).

6 Okonkwo (1996).

7 Barron's Booknotes (1993).
} 
too often took the sacred words in a harsh, literal sense rather than with a spirit of mercy and compassion. At the same time many of these social and religious dogmas did more to keep the poor serving the new wealthy middle classes than to promote the good of humanity.

The Booknotes are accurate, for dogma undeniably works against Tess and is instrumental to her suffering. As already pointed out, a formidable corpus of contributions follow this line of thought, among which is a critique by Laura Claridge ${ }^{8}$ which merits attention on account of its intriguing revelation not only of Tess but of Tess's creator, Hardy. Claridge proposes that the stringency of Victorian culture is evident as much in its hold over the author as in its hold over the heroine. Claridge maintains that Hardy is not as immune to the ethical beliefs of his day as he imagines, and she refers to his ambivalence in sexual matters to demonstrate this. By enveloping each of Tess' sexual encounters in confusion, Claridge notes, Hardy casts a shroud over the correct circumstances in which such an encounter should occur. In accordance, the conservatism that he overtly rejects emerges covertly in his indecisive handling of his heroine's eroticism. The review concludes: "Hardy inevitably, if accidentally, suggests the very convention he would deny: that an unmarried woman be sexually inexperienced remains of utmost importance in judging her value" (p. 66).

The analysts argue unanimously that cultural turgidity is a problem in Tess's world. Apart from this problem, her downfall is frequently attributed to the malevolent dealings of fatethe "Spirit Sinister", to use Laurence Lerner's famous phrase- or to her own hypersensitivity. But while cultural turgidity is material to discourse on Tess, it is nowhere evident that it has been explored with recourse to Said's thesis, or that Tess's persistent re-positioning has been seen from the aspect of a culture invalidating one of its own intrinsic concepts.

Before winding up this section, reference should be made to one of our earlier papers on Tess and Arrow of God. ${ }^{10}$ We compared iconicity in the two texts, applying the three types of icon-viz. the image, the diagram, and the metaphor - to the mental reconstructions of the reader and the writer. Being a linguistic appraisal based on the theory of the semiotician, C.S. Peirce, it quite naturally did not do justice to the wealth of literary symbolism in the novels. The present study hopes to redress this.

In summary, much has been written on the texts but nothing in the way of a literary comparison of the protagonists' movement as symbolic of cultural adjustment in two cultures of varying textures. Umuaro's culture is generally more elastic, as will be seen, while that of Wessex and its environs is generally more rigid. Ezeulu and Tess are analogous of core elements within their cultures, and their centralization, and later marginalization, reflects the native tendency of culture towards grading of its elements as well as the positive and negative sides of cultural fluidity. A closer look at the novels will make the analogy clearer and aid an objective reading of the authors' portrayal of cultural adjustment.

\section{Centralization}

Commenting on Ezeulu, Okonkwo afore-mentioned posits that Achebe "conceives this character partly in the light of anthropological theories which portray priests as the

\footnotetext{
${ }^{8}$ Claridge (1993).

9 Lerner (1975).

${ }^{10}$ Masagbor and Akhuemokhan (2007).
} 
intellectuals of tribal society" (p. 108). Ezeulu may consequently be deemed emblematic of the intellectual limb of his society. And he may equally be deemed emblematic of something else or something weightier, because it is manifest that his larger-than-life quality, which many literary analysts have attested to, makes him seem more of an institution than an individual at the start of events in Arrow of God. As the celebrated priest of Ulu, the major deity of the six clans that constitute Umuaro, he is a pivotal figure. He influences the greatest and least of the people's decisions; regulating their monthly calendar, sitting in the elders' meetings, and acting as a mediator between them and their god. Ezeulu is an interesting fusion of the clan's political, economic, and spiritual concernsperhaps not representative of its entire culture but definitely representative of an innate part of it. A graphic illustration of his initial place at the heart of the community occurs early in the narrative during the Feast of the Pumpkin Leaves. During the feast, he officiates at the centre of the market place ringed around by the inhabitants of all the six villages. The men form the outermost ring, the women the inner ring, the six messengers circulate within the arena proper, and he presides at the nucleus. He is painted half black and half white in token of his affinity to the physical and spiritual life of Umuaro respectively. The paint underscores his peculiarity and simultaneously denotes him as a cohesive agent on two levels; first on the vertical level, between earth and heaven, and second on the horizontal level, bonding neighbour to neighbour in a vivid expression of communal solidarity. Hence he functions as a magnet, coordinating a ceremony which induces the scrutiny of the gods above and pulls the community together below. In the forthcoming scene taken from the feast, the men station themselves in the background to give moral support, and the women actively participate in an exercise which Ezeulu marshals with authority:

By now Ezeulu was in the centre of the market place. He struck the metal staff into the earth and left it quivering while he danced a few more steps to the Ikolo which had not paused for breath since the priest emerged [....] Then he pulled the staff out of the ground and with it in his left hand and the Mother of Ofo in his right he jumped forward, and began to run round the market place [...]

The six messengers followed closely behind the priest and at intervals, one of them bent down quickly and picked up at random one bunch of leaves and continued running $[\ldots .$.

As if someone had given them a sign, all the women of Umunneora broke out from the circle and began to run round the market place, stamping their feet heavily [....] Then the women of Umuagu [...] no one ran out of turn. (AG 72-73)

Literally and figuratively, everything revolves around Ezeulu. He plainly encapsules something momentous in his community. We take him as symbolic of a core phenomenon in his people's culture, which is also undoubtedly a vibrant, or living, phenomenon. The vibrancy of the phenomenon is indisputable because despite the chief priest's years, the Feast of the Pumpkin Leaves and the other ordinances that he conducts cannot be misconstrued as defunct cultural habits. A quick comparison with the May Day dance, a traditional ceremony at the beginning of Tess which incidentally also features women predominantly, brings this out. Hardy's May-Day dance is an "old custom" (TD 10) which has lingered on. Ironically, it conveys a sense of forlornness irrespective of the fruitfulness associated conventionally with May. As a prelude to the dance, members of the women's club of Marlott march through the streets in pairs, looking uncomfortable and odd as they process towards the village green where the dance will be held. Their gowns have been faded or bleached to multifarious shades of white- "no two whites were alike among them" (11) — and a number of the marchers are well advanced in life; "[M]iddle-aged and 
even elderly women [...] with silver-wiry hair and wrinkled faces" (11). When the men begin to come they come in trickles, and even though the fête eventually gets underway only a fraction of the community is in attendance. Placing this strained dance tangential to the former lustier one in Umuaro makes the difference palpable between a dying custom and a living one.

Tess is a very different protagonist from Ezeulu but she too can be regarded as a pivotal figure initially. Again, her position at the nucleus of events can be illustrated graphically as a bull's eye surrounded by a number of rings. The first ring surrounding her is her immediate family, which looks to her as the breadwinner. She is just 16 , the eldest of six siblings, but seemingly more responsible than either of her parents. Her father is an alcoholic and her mother is too easy-going to worry seriously about raising her brood. Tess is therefore the mainstay of the household. She is the one that carries the bee-hives to the market on the ill-starred night that her horse is killed in an accident with the mail cart. When this source of revenue is cut off, she is also the one that goes searching for the Stoke D'Urbervilles and thereafter, begins working for them. From beginning to end she assumes responsibility for her family's survival, going as far as arranging for a family marriage to be conducted posthumously (Tess enrolls her husband to marry her sister, Lisa, after Tess has been executed).

The second ring surrounding Tess is a circle of male attention. Tess is the object of concentration, like the prima donna or the queen bee, while the principal male characters in the text rotate around her. Alec singles her out for attention among the girls at Tantridge, and Angel Clare does likewise among the milkmaids at Talbothays dairy. And having captured their attention, for good or for evil she sustains it throughout the novel, because once the primary contact has been established, there is no point at which they effectually break out of her orbit. Alec betrays his evangelical calling to claim her, a second time, as his mistress; and Angel returns from faraway Brazil to claim her, also a second time, as his wife. No matter the distance in space or in social standing, they keep returning to her until she puts an end to their interminable circuiting by killing Alec.

The third ring surrounding Tess is a communal ring. The reader learns that she is not only a pivotal figure in the immediate Durbeyfield family and the lives of the eligible bachelors in Wessex but, quite unintentionally, is a communal figurehead in addition. She is allied to a name that is meant to turn things around- "D'Urberville" - the original version of her own corrupted "Durbeyfield". It is a name that speaks of a venerable English tradition, the nobility; a concept which proves to reside at the soul of Victorian society in spite of the technological leanings of the age. The D'Urbervilles were an ancient family that ruled the countryside with tremendous authority, and even in Tess's day, when all that is left of their splendour are some dilapidated estates and a chain of marble tombs, their name is held in reverence. In the opening chapter, for example, the reader sees the effect that the historic name "D'Urberville" has on the protagonist's father. On learning that he is of distinguished D'Urberville origins, Tess's father, hitherto "plain Jack Durbeyfield, the haggler" (p. 4), instantly bequeaths upon himself the title "Sir John." The news of his heritage reaches him while he is on the road to his cottage. He refuses to take another step; rather, in the manner of the fashionable world he has just entered, he orders a horse and carriage to "carry [him] hwome" (p. 7).

Tess's mother sends her daughter to seek the wealthy Stoke D'Urbervilles purely on the strength of their shared name, "D'Urberville." Later in events, Angel Clare determines to use the name to elevate Tess in front of his middle-class parents: "My mother [...] will think so much better of you on account of it," he tells Tess (p. 202). The name is scheduled to make Tess acceptable to the Clares before the marriage, and approve her to a 
"hopelessly snobbish" society after it (p. 242). Beyond this, it will form the cradle of their new life together, for Angel decides that they should honeymoon in an old farmhouse that was once part of a D'Urberville mansion. Consequently the appellation "D'Urberville" alone is a reel in the sense that it is a polar axis in the society, and in the sense that it allegedly has the potential to somersault the heroine into good luck.

There is another dimension to the symbolism of Tess's name, and that is its evocation of dying cultural habits. For although the concept of nobility and much that followed in its train at the outset - chivalry, grandeur, the pastoral existence-lies at the soul of Victorian culture, it cannot be said to signify a thriving tradition. Indeed one of the rewards of a comparison of Arrow of God and Tess is discovering how Achebe successfully manages to link an old man to vibrant cultural elements, while Hardy, with equal success, manages to link a young girl to declining elements. A perceptible index that Tess stands as a figure of disintegrating cultural elements is the corruption inherent in her name; the resonant "D'Urberville" having been toned down and countrified to become "Durbeyfield". A second index which conveys the symbolism of disintegration more decisively is found in the old farmhouse where Tess and Angel retire for their honeymoon. The newly-weds see a couple of paintings hanging on the wall:

[Angel] looked up, and perceived two life-size portraits on panels built into the masonry. As all visitors to the mansion are aware, these paintings represent women of middle age, of a date some two hundred years ago, whose lineaments once seen can never be forgotten. The long pointed features, narrow eye and smirk of the one, so suggestive of merciless treachery; the bill-hook nose, large teeth and bold eye of the other, suggesting arrogance to the point of ferocity, haunt the beholder afterwards in his dreams $[\ldots .$.

The unpleasantness of the matter was that in addition to their effect upon Tess, her fine features were unquestionably traceable in these exaggerated forms. (p. 277)

Granted that Tess's "fine features" are an aesthetic improvement on the "exaggerated forms" of her predecessors, the discrepancy between the various profiles is nonetheless a compendium of the collapse of a great house and its prestigious way of life. The D'Urbervilles in their heyday were a powerful and intimidating force, simulated in the huge and bold features of the women in the painting. Their waning over the years to a shadow of their bygone glory is simulated in the faint D'Urberville features of their descendent, Tess. In essence, Tess is just a ghost of the original D'Urberville, embodying in her corrupted name and her weakened features a dying family and a dying tradition.

Thus it can be seen that Tess is synonymous with a core phenomenon in her people's culture, which is also a disintegrating phenomenon. When we place her side by side with Ezeulu on the symbolic drawing board, we see them as a pair, as radial points in a matching set of communal organisms. The obvious disparity is that in one instance, that of Ezeulu, a living element is at mid-section, whereas in the second rather unusual instance, a dying element is at mid-section. Such conjecturing might appear to be nothing but mental sketching of the narrative material, however it re-iterates unmistakably the singularities of the cultures being described and the authors' attitudes to these cultures. For example, if culture in Arrow of God is represented in a diagram, Ezeulu's centralized position works artistically to proclaim Achebe's approval of Umuaro. The core position of a living phenomenon is indicative of a healthy and fluid society in which the "heart" is alive, thereby guaranteeing life and movement throughout the whole. Under these circumstances, energy is the defining trait of the entirety, and there is little possibility of a disintegrating phenomenon being left to stagnate at the centre, as occurs in the case of Wessex. Rather, 
anything threatening to become debris will be automatically flushed out with the bloodstream-a principle which is played out with tragic effect in the very pages of the text. In substance, the vital force at the bosom of the organism, and the flux and flow which naturally emanate from the vitality, are explicit signs of a dynamic and liquid culture. The symbolism reinforces Achebe's pre-eminent motif of a flourishing flexible pre-colonial society.

Tess's centralized position works artistically to the same effect. Tess is a metaphor for a cultural phenomenon in the Victorian set-up, which is less mobile and tends to keep things strictly in place. As noted earlier, she stands as a figure of dying cultural elements, and the fact that a phenomenon can virtually dissolve at the centre of the hypothetical cell and not be removed is indicative of the paralysis that marks that culture. It is imperative that the reader conceptualize the scenario in order to appreciate the allusion. The picture of Wessex is of a large cell with a stark disintegrating spot at its breast. This underscores two facets of the culture Hardy is reproducing: that the civilization as a whole is jeopardized by morbidity; and that top priority is given to habits and beliefs that should since have been done away with. Hardy is not proposing that the tradition of nobility specifically is unhealthy, but that Victorian society in the main was prone to holding onto unhealthy traditions. In effect the picture is a denunciation of a civilization the author estimates to be unyielding and dominated by false values.

\section{Marginalization}

The demotion machinery in a culture seems to differ in conformity with the culture's texture. Events in the novels confirm the adage that there are two faces to every coin; the liquid culture has its drawbacks, and the turgid one has its benefits. Achebe and Hardy would not be writers of their calibre if they did not unveil the two sides. When it comes to the issue of cultural adjustment there is a reversal in evaluations, and Ezeulu's brisk ejection to the periphery discloses an unsavoury humour in Umuaro's fluidity, even as Tess's step-by-step relocation encourages a reappraisal of a culture that holds its customs almost stationary over generations.

Aside from all that has been said about Umuaro thus far, its fluidity infers absorption, which is the signature of more than one of Achebe's traditional societies. A case in point is Umuofia in his acclaimed novel Things Fall Apart. ${ }^{11}$ Umuofia's capacity to absorb whatever comes its way is lauded in a series of proverbs: "Eneke the bird says that since men have learnt to shoot without missing, he has learnt to fly without perching" (Things Fall Apart 16); "[t]he clan was like a lizard, if it lost its tail it soon grew another" (p. 121); and so on. As the critic, Umelo Ojinmah, ${ }^{12}$ rightly asserts: "The society's ability to adapt to any situation [...] is a survival mechanism" (p. 20). As it is in Umuofia so it is in Umuaro, and nobody would quarrel with a people's desire to survive. A problem surfaces, however, because the dividing line between being adaptable and being fickle is often precariously slim, and the clan can be adjudged in its dealings with Ezeulu. It subordinates its paramount spiritual watchman and intercessor with alarming ease- he translates from "a kind of priest-king in Umuaro" ( $A G$ 38) to a condition reminiscent of paltriness "almost overnight” (p. 211). Admittedly the community escapes whole after his send-off, but not

\footnotetext{
11 Achebe (1958).

12 Ojinmah (1991).
} 
without a dent on its dependability. Be that as it may, his shift demonstrates cogently the speed at which adjustment can take place in a supremely liquid society.

Ezeulu's marginalization is swift. He maintains a consistently central position until Obika's death a few days before the New Yam harvest, and then experiences a full and abrupt eclipse. As before, his centralized position can be envisaged as a bold dot amidst an array of rings. The protagonist remains under the spotlight as a focal point, a magnet, and an arresting performer. The other characters - the inhabitants of Umuaro, Okperi, and Government-Hill—range themselves around him, figuratively speaking, watching his every move. It is intriguing to note that the opening picture of Ezeulu, the painted priest at the Feast of the Pumpkin Leaves with the rings of men and women surrounding him, is sustained metaphorically almost to the close of the text. He continues to function as the colourful individual in the thick of events, keeping the community electrified with his unorthodox behaviour and causing all eyes to be ever fixed on his person.

One way or the other he is regularly a point of reference. As a positive point of reference he is the chief priest of the chief deity, and the sole voice that challenges the idea of a mission to Okperi, a venture which ends in disaster as he predicts. Added to this is his impressive compound, his outstanding wealth as evidenced in the marriage he hosts, and the exceptional good looks of his family. On the other hand, as a negative reference point his younger son, Oduche, does the unthinkable when he locks up the sacred python in a box, and his favourite son, Obika, is whipped for going late to build the white man's road. Half-way through the text Ezeulu travels to Government Hill, Okperi, but the change in location does not detract from his centralized position. On the contrary it accentuates it because Government Hill is the headquarters of British Administration in the province, and even from his prison cell his story is on all lips. The health of Captain Winterbottom for instance-which Ezeulu is reportedly monitoring by magical devices-is only of interest to the Africans as far as it relates to Ezeulu, and his haughty rejection of a chieftaincy appointment sends currents through his audience that reminds them that he is eternally Ezeulu, the magnet. In fact the ripples of excitement he generates from his confinement fan out through Okperi and Umuaro in a fashion that replicates the prevailing pattern of a dot in the middle of dilating spheres; the regular bulls-eye picture, but mirrored in water.

Ezeulu returns to Umuaro and every eye remains glued to him, albeit in hostility, when he refuses to call the New Yam festival. Invariably, his son dies and the impact is like a minor earthquake, beginning in his compound and spreading abroad: "Obika's death shook Umuaro to the roots" p. 220). The conclusion to be drawn from these episodes is that any physical movement Ezeulu makes is superficial to his basic centrality. His stature in the community is comparatively undiminished until the moment that suddenly, everything caves in. The earthquake is the last of the ripples he creates. Obika departs and "a few days after" (p. 230) his father is at the fringes of communal activity.

Achebe's choice of language in describing the transition is thought-provoking - "almost overnight", "a few day's after". They raise vague misgivings in the reader's mind about a society which can so smoothly switch from one cultural habit to another. For the people troop to the Christian harvest, bypassing a convention (the New Yam Festival) which only the previous year had attracted "every grown man in Umuaro" (p. 202). And for the crowd that decamps there is no going back. "Thereafter any yam harvested in [its] fields was harvested in the name of the son" (p. 230, emphasis added). This is the closing sentence of the novel, delivered with a tone of finality. The reader ponders over the fluid society of Umuaro and concedes, with some regret, that anything liquid readily gives way under pressure. 
The implications of Umuaro's liquidity become plainer when it is juxtaposed with a structure that is not so liquid and adjusts less spontaneously. Culture in the region of Wessex is relatively fixed, and as usual this has its connotations; immobility, as already established, and solidity. In such a setting, customs are to some extent anchored. They are given opportunity to mature, then to crystallize, and when they die they do so at a ripe old age and not "in full bloom" ( $A G$ 209), as occurs in Umuaro. Adjustment in Wessex, when it comes, is by degrees, and in acknowledgement of this Tess's marginalization is suspended.

It could be argued that Tess remains a central figure to the end in a similar manner to Ezeulu in that she remains a key domestic, sexual, and social symbol. This is correct, but it fails to take cognizance of a major stylistic difference between Arrow of God and Tess. Achebe calculatedly foregrounds the centralized position of his protagonist until the climax of the novel, while Hardy progressively backgrounds his own protagonist. One may deduce from this that Achebe's intention is for Ezeulu's epilogue to have a cataclysmic effect, whereas Hardy's objective for his own heroine is a quiet journey into oblivion. As a result of Achebe's stylistic preference, it is impossible to forget that Ezeulu is a communal hub since Umuaro's business continues wheeling around him. In contrast, it is easy to forget that Tess is a pivotal figure because she passes through a chain of experiences which ostensibly defeat her and gradually deflate her importance. The apparent slowness of her relegation fits in with Hardy's sketch of a culture in which processes are typically protracted, be they processes of deterioration or processes of adjustment.

Since dots and circles are recurring signs in the two texts they can be aptly utilized to delineate Tess's transposition from the middlemost footing in the communal cell to the circumference. The semblance this time is not of a dot on a target board, but of a dot spiraling away from its gravitational point towards the outer regions of the unit. As always, the dot is the protagonist i.e. a core cultural element, and each curl in the spiral brings about a shift that takes the dot somewhat farther from its centralized post. In relation to marginalization, it presupposes an elongated but continuous displacement programme. Each curl in the symbolic spiral also denotes a circle of events in the protagonist's biography. Because the movement is winding, the separate circles do not close neatly but finish in non-alignment, indicating that each turn of affairs leaves Tess slightly worse off as opposed to leaving her precisely where she started. An overview of the plot helps render the pattern transparent. The first circle of events is in Tantridge. Tess leaves her home, goes to the Stoke D'Urbervilles, and returns to her home pregnant. The circle terminates with the loss of her illegitimate child, Sorrow, subsequent upon which she is worse off than she was at the beginning because she is no longer "pure". Metaphorically, she therefore spirals a space away from the "centre", the position of primacy and the ideal, in the direction of obscurity. Tess moves next to Talbothays, the dairy-farm where she re-unites with Angel Clare. There is a second circle-Clare abandons her as Alec abandoned her-and Tess swivels another space away from the ideal because the stigma of being an abandoned wife now supplements the stigma of pre-marital motherhood.

She moves to Flintcomb Ash. As may be inferred from its linguistic composition, "flint" and "ash", it is a hard cold environment, the antithesis of Talbothays. The attention Tess now attracts is from rustic characters rather than enlightened men. She shears off her eyebrows, covers her face, and re-assumes wearing old clothes. At this juncture Alec finds her again and the old relationship is renewed, only this time Tess is willing. She becomes his mistress, which elevates her financially but sinks her lower socially and morally. In other words, there is another detrimental cycle-Alec coming, then going, then coming back-which ends with Tess relinquishing her original values and settling for common-law 
marriage. History repeats itself and Clare finds her a second time as Alec found her. The old relationship is likewise renewed but not before she kills Alec, whereby she provokes the final twist in the spiral that moves her from the position of mistress to the position of murderess, and from there to the gallows. It can be seen that the plot is modelled on a chain of convolutions that finally deposit Tess on the remotest rim of Victorian society. Therefore in spite of the prolonged passage, at the end of the day her situation matches that of Ezeulu in that they both become social outcasts. At the point at which they become stigmatized the process of demotion can be said to have resulted in interdiction, perhaps the severest measure of culture as a differentiating agent.

Returning to the concept of a cultural whole and cultural parts, the two preceding outlines of cultural adjustment betoken marginalization procedures in cultures of varied fabric. Ezeulu's full-drive marginalization implies a sweeping adjustment manoevre in which a core phenomenon is radically taken to the sidelines, and maybe thence into extinction, as was postulated in the inaugural comments on culture. The deftness of the manoevre re-iterates the fact that Umuaro is a liquid culture and that certain behaviours accompany the liquidity. For example, it would be unreasonable to ask a liquid entity to provide a foothold, or an elastic entity to keep its shape when stretched. Had Ezeulu reflected on this, and on the natural make-up of his society, he would have guessed that when faced with a life-and-death dilemma of the sort Umuaro faces, the clan would not stand behind him for any length of time. It is a reality which Achebe takes in his stride. He describes the chief's priest's exit with a practicality that communicates his knowledge that such casualties, though disturbing, are part and parcel of that particular civilization.

Tess's metamorphosis is retarded and casts a mildly different complexion on the hitherto unedifying non-elastic Victorian culture. Unlike the elastic one, it does not bend at will to fit the circumstances, and the same rigidity that obstructs the free flow of phenomena also serves to preserve them. Slow and steady is the order of the day, and the schematic imitation of a core phenomenon being turned over and over systematically as it recedes into the background captures cardinal traits of the culture Hardy is describing. The inference is of a meticulous, deliberative, and scientific people, whose time-revered habits and capabilities are not quickly open to negotiation.

\section{Conclusion}

Ezeulu and Tess; the proud hero and the self-effacing heroine. They are undeniably different, and yet they are used to tell the same tale of a transference from centre-stage to the wings. We have taken them to be analogous of core elements in their cultures, and have tried to illustrate that their initial centralization, and later dislodgment, reflects a grading tendency that is inherent in culture comprehensively. It reflects equally the fluidity or otherwise of the explicit cultures studied. Initially, Ezeulu is the figure at the centre of the picture in Umuaro. He is visualized as an immense decimal point where communal forces converge, a thriving element deep-seated in a liquid organization that Achebe patently sanctions. Tess, the figure at the centre of the picture of Wessex, is also a decimal point but built on smaller proportions than Ezeulu. She is akin to a gently perishing heartbeat, signaling a civilization on the verge of total insensibility, whose system of opinions Hardy ranks poorly.

Their centralization gives way to decentralization and the texture of the various cultures is italicized. On account of Umuaro's liquidity the tide of its events is rapid, which means that adjustment is commensurately rapid, even to a fault. In consequence, Ezeulu's 
deportation is effected with minimum delay and without sentiment, presenting itself as a dot streaking to the perimeter of the cultural graph. Tess's marginalization is long-term, invoking an aura of nostalgia and of loyalty to tradition. It unveils the softer side of Hardy, the patriot in love with English folklore, and presents itself graphically as a dot coiling leisurely outwards. In summary, whether dot, bulls eye, ring, or spiral, the collocation of specks and circles contains a message that harmonizes with themes running through the texts. This is not to presume that nothing happens slowly in Umuaro, or that nothing is accelerated in Wessex, but merely that the two civilizations have conspicuous features which have prompted our symbolic translations.

Open Access This article is distributed under the terms of the Creative Commons Attribution Noncommercial License which permits any noncommercial use, distribution, and reproduction in any medium, provided the original author(s) and source are credited.

\section{References}

Achebe, C. (1958). Things fall apart. London: Heinemann.

Achebe, C. (1974). Arrow of God. Oxford: Heinemann.

Barron's Booknotes (1993). The author and his times. Barron's Booknotes for Tess of the D'Urbervilles. 8 July 2005. http://pinkmonkey.com/booknotes/barrons/tessurb1.asp.

Claridge, L. (1993). Tess: A less than pure woman ambivalently presented. In P. Widdowson (Ed.), Tess of the D'Urbervilles: Thomas Hardy (pp. 143-153). London: Macmillan.

Hardy, T. (1994). Tess of the D'Urbervilles. London: Penguin.

Lerner, L. (1975). Thomas Hardy's the mayor of Casterbridge. Sussex: Sussex, UP.

Masagbor, R., \& Akhuemokhan, S. (2007). The artist and the demise of a culture: A comparative study of iconicity in Achebe's Arrow of God and Hardy's Tess of the D'Urbervilles. Biudiscourse, 1, 37-46.

Ojinmah, U. (1991). Chinua Achebe: New perspectives. Ibadan: Spectrum.

Okonkwo, C. (1996). Time, number, man and deity: Igbo civilization in Chinua Achebe's Arrow of God. In E. Ihekweazu (Ed.), Eagle on Iroko: Selected papers from the Chinua Achebe international symposium 1991 (pp. 105-123). Heinemann: Ibadan.

Posner, R. (1989). What is culture? In W. A. Kosh (Ed.), The nature of culture (pp. 240-295). Bochim: Brockmayer.

Said, E. W. (1983). The world, the text, and the critic. Cambridge: Harvard UP.

Tylor, E. B. (1871). Primitive culture. London: Murray. 